\title{
PENGUATAN ENTREPRENEUR UMKM MELALUI PELATIHAN SISTEM INFORMASI PENCATATAN KEUANGAN BERBASIS ANDROID PADA KOPERASI JASA KOMUNITAS ENTREPRENEUR KELURAHAN PERWIRA BEKASI UTARA
}

\author{
STRENGTHENING MSME ENTREPRENEURS THROUGH TRAINING \\ ANDROID-BASED FINANCIAL RECORDING INFORMATION SYSTEM \\ IN THE ENTREPRENEUR COMMUNITY SERVICE COOPERATIVE \\ KELURAHAN PERWIRA BEKASI UTARA
}

\author{
Budi Indrawati*, Elia Rossa, Supriyanto \\ Fakultas Ekonomi dan Bisnis, Universitas Bhayangkara Jakarta Raya, \\ Jalan Perjuangan Raya Bekasi \\ *Email: budi.indrawati@dsn.ubharajaya.ac.id \\ (Diterima 12-03-2021; Disetujui 27-03-2021)
}

\begin{abstract}
ABSTRAK
Anggota Koperasi Entrepreneur Kelurahan Perwira Bekasi Utara sebagai mitra kegiatan pengabdian kepada masyarakat adalah para entreprenur UMKM, terdiri atas usaha kuliner, maupun pedagang barang jadi. Salah satu permasalahan mitra anggota koperasi entrepreneur yang menjadi prioritas untuk didampingi adalah masalah pencatatan keuangan dan pembuatan laporan keuangan. Tujuan kegiatan pengabdian kepada masyarakat ini adalah untuk memperkuat dari sisi pencatatan keuangan usaha mitra, agar pencatatan keuangan usaha mitra anggota koperasi entrepreneur menjadi lebih mudah, efektif dan efisien dan akan mendukung perkembangan usaha mitra ke depan nantinya. Metode kegiatan dengan metode penyuluhan dan metode pelatihan praktek penggunaan pencatatan keuangan dan pembuatan laporan keuangan dengan menggunakan sistem informasi pencatatan keuangan aplikasi berbasis android SIAPIK (Sistem Informasi Aplikasi Pencatatan Informasi Keuangan) dari Bank Indonesia. Peralatan yang digunakan adalah menggunakan ponsel masing-masing peserta. Hasil dari kegiatan ini adalah anggota koperasi yaitu para entrepreneur, paham dan mampu menggunakan aplikasi SIAPIK, dilihat dari hasil evaluasi bahwa peserta puas. Kesimpulan bahwa peserta paham dan mampu menggunakan aplikasi SIAPIK. Saran perlu pelatihan di bidang pemasaran, kualitas produk, jasa dan kualitas layanan.
\end{abstract}

Kata Kunci : Koperasi, Kewirausahaan, SIAPIK, UMKM

\section{ABSTRACT}

Members of the Entrepreneur Cooperative of Kel.Perwira Bekasi Utara as partners for community service activities are MSME entrepreneurs, consisting of culinary businesses, as well as traders of finished goods. One of the problems of entrepreneur cooperative member partners that is a priority for assistance is the problem of financial recording and making financial reports. The purpose of this community service activity is to strengthen in terms of partner business financial records, so that business financial records of entrepreneur cooperative member partners become easier, more effective and efficient and will support the development of partner businesses in the future. Activity method uses the extension method, then the practical training method for the use of financial records and the preparation of financial reports using the information system for financial recording applications based on the Android application SIAPIK (Information System for Financial Information Recording Application) from Bank Indonesia. The equipment used is to use each participant's ponsel. The results of this activity are cooperative members, namely entrepreneurs, who understand and are able to use the SIAPIK application, it can be seen from the evaluation results that the participants are satisfied. The conclusion is that the participants understand and are able to use the SIAPIK application. Suggestions need training in marketing, product, service and service quality.

Keyword : Cooperative, Entrepreneur, SIAPIK, MSME 
Penguatan Entrepreneur Umkm Melalui Pelatihan Sistem Informasi Pencatatan Keuangan Berbasis Android Pada Koperasi Jasa Komunitas Entrepreneur Kelurahan Perwira Bekasi Utara

Budi Indrawati, Elia Rossa, Supriyanto

\section{PENDAHULUAN}

Koperasi menjadi penting ketika setiap entrepreneur mampu memilih sebuah bisnis bersama komunitas mereka dan pastinya membuat berbagai kesamaan dalam bisnis. Oleh karena itu, perlu rasanya pendidikan dan praktek pengelolaan koperasi mulai dipikirkan oleh para entrepreneur dalam menjalankan bisnis untuk menggapai kesuksesan (Ramadhan, 2016). Saat ini, tidak ada kegiatan dan sektor yang bisa lepas dari teknologi informasi. Hampir semua memanfaatkan teknologi, baik langsung maupun tidak langsung, untuk itu koperasi harus memanfaatkan teknologi informasi dalam perkembangannya.

Salah satu teknologi tersebut adalah Sistem Aplikasi Pencatatan Informasi Keuangan (SIAPIK). SIAPIK merupakan aplikasi pencatatan informasi keuangan yang memudahkan pengusaha khususnya usaha mikro kecil dan menengah (UMKM) untuk bisa membuat neraca, laporan keuangan, dan laba rugi melalui ponsel android. Sistem aplikasi ini dapat digunakan oleh semua pengusaha UMKM dengan mengunduh program tersebut secara gratis melalui ponsel android di google playstore (Indonesia, 2018).

Pemanfaatan teknologi lainnya, adalah pemanfaatan e-commerce dalam operasional bisnis, entrepreneur UMKM akan mendapatkan akses pasar yang lebih luas dan berpeluang menarik pelanggan baru. Pelanggan akan lebih mudah mendapatkan informasi yang diperlukan secara online (Yasin, 2018).

Lima permasalahan yang dihadapi UMKM, yaitu 1). Permodalan, 2).Distribusi barang, 3). Perizinan, 4). Pembukuan yang masih manual, 5). Masih kurang adaptasi dengan pemasaran online (Wahyu, 2017).

Seperti negara berkembang lainnya, daya saing UMKM Indonesia relatif rendah, alasannya: 1) kualitas buatan UMKM lebih rendah dari barang impor, teknologi rendah, SDM yang buruk, termasuk manajemen dan pemasaran, 2) Tingkat efisiensi proses produksi relatif tinggi, dan 3) Kebijakan ekonomi makro Indonesia, tanpa sengaja lebih menguntungkan barang impor (Tambunan, 2012).

Masalah UMKM lainnya adalah kesadaran mencatat yang rendah, pencatatan dianggap sulit, skala usaha kecil/sederhana, dan keuangan bercampur antara keuangan usaha dengan keuangan kebutuhan rumah tangga UMKM sehari-hari. Akibat dari tidak adanya pencatatan usaha, maka UMKM tidak mengetahui kondisi finansial usahanya, bank sulit menganalisa kemampuan UMKM, dan seringkali analisa kredit tidak akurat, butuh waktu dan biaya.

Sulitnya memperoleh fasilitas pinjaman modal tanpa jaminan memang menjadi kendala yang sering dialami pelaku entrepreneur UMKM. Hal ini dialami oleh 
entrepreneur UMKM di Kabupaten Bekasi. Jalan satu-satunya, kepala daerah harus mengambil langkah-langkah yang kongkrit bahkan tegas dalam menelaah kesulitan yang dihadapi para pelaku usaha di Kabupaten Bekasi. Untuk itu, Dinas Koperasi dan UMKM Kabupaten Bekasi memberikan fasilitasi bantuan permodalan dari perbankan terhadap pelaku entrepreneur UMKM Kabupaten Bekasi. Dengan dilakukannya fasilitasi tersebut diharapkan pelaku usaha mengerti dan memahami prosedur mengenai proses peminjaman di lembaga keuangan (Entah Ismanto, 2017).

Pentingnya penyusunan laporan keuangan bagi UMKM sebenarnya bukan hanya untuk kemudahan memperoleh kredit dari kreditur, tetapi untuk pengendalian aset, kewajiban dan modal serta perencanaan pendapatan dan efisiensi biaya-biaya yang terjadi yang pada akhirnya sebagai alat untuk pengambilan keputusan perusahaan. Untuk memulai menerapkan pencatatan akuntansi para pengelola usaha harus mempunyai pikiran yang formal, artinya bisa memisahkan kepentingan keuangan usaha dengan pribadi.

Beberapa manfaat dari akuntansi apabila diterapkan oleh para pelaku UMKM antara lain: 1) Dapat mengetahui kinerja keuangan perusahaan, 2) UMKM dapat mengetahui, memilah dan membedakan antara harta perusahaan dengan harta pemilik, 3) UMKM dapat mengetahui posisi dana, baik sumber dana maupun pengeluarannya, 4) UMKM dapat membuat anggaran yang lebih akurat, 5) UMKM dapat menghitung pajak, dan 6) UMKM dapat mengetahui aliran uang tunai/cash flow selama periode tertentu (Supriono, 2015).

Melihat manfaat dari akuntansi, para pelaku UMKM harusnya sadar bahwa akuntansi penting bagi perusahaan mereka. Penggunaan akuntansi dapat mendukung kemajuan, khususnya dalam hal keuangan, peningkatan laba juga dapat direncanakan dengan menggunakan akuntansi. Dengan tingkat laba yang semakin meningkat, perkembangan UMKM akan menjadi semakin lebih baik sehingga UMKM akan benar-benar menjadi salah satu solusi bagi masalah perekonomian di Indonesia. Pembuatan laporan keuangan untuk UMKM ini mengacu pada Standar Akuntansi Keuangan Entitas Tanpa Akuntabilitas Publik (Supriono, 2015).

Menurut Ketua Koperasi Komunitas Entrepreneur Bekasi, permasalahan utama bagi anggota Koperasi Jasa Entrepreneur Kelurahan Perwira Bekasi adalah kurangnya permodalan dan rendahnya kemampuan dalam menyusun administrasi keuangan, serta kesulitan dalam pemasaran, dan kurangnya keterampilan SDM serta manajerial, juga kualitas produk yang terutama bagi produk usaha kuliner.

Melihat dari uraian di atas, maka justifikasi pengusul tim pengabdian kepada masyarakat bersama mitra dalam menentukan pembatasan persoalan prioritas yang 
Penguatan Entrepreneur Umkm Melalui Pelatihan Sistem Informasi Pencatatan Keuangan Berbasis Android Pada Koperasi Jasa Komunitas Entrepreneur Kelurahan Perwira Bekasi Utara

Budi Indrawati, Elia Rossa, Supriyanto

disepakati untuk diselesaikan selama pelaksanaan program PKM adalah: 1) Masalah pencatatan keuangan, dan 2) Masalah pembuatan laporan keuangan. Oleh karena itu, tim pengabdian kepada masyarakat memberikan pelatihan pencatatan keuangan yang sederhana dan benar melalui aplikasi SIAPIK. Sebagai referensi kegiatan pengabdian kepada masyarakat terdahulu adalah dari kegiatan pengabdian kepada masyarakat Rinandiyana et al (2020), dan pengabdian kepada masyarakat Dewi et al (2020), serta pengabdian masyarakat Wiratama et al (2019).

Tujuan kegiatan pengabdian kepada masyarakat ini untuk memperkuat dari sisi pencatatan keuangan usaha mitra: 1) Untuk mengetahui peserta paham dan mampu membuat pencatatan keuangan dengan menggunakan aplikasi SIAPIK, 2) Untuk mengetahui peserta paham dan mampu membuat laporan keuangan dengan menggunakan aplikasi SIAPIK, dan 3) Untuk mengetahui evaluasi level reaktif terhadap pelatihan penggunaan aplikasi SIAPIK.

\section{BAHAN DAN METODE}

Lokasi kegiatan pengabdian kepada masyarakat dilaksanakan di Komplek Prima Harapan Regency Kelurahan Harapan Baru Kecamatan Bekasi Utara Propinsi Jawa Barat. Tepatnya Ruko Prima Harapan Regency di Kizoku Center.

Waktu pelaksanaan kegiatan pengabdian kepada masyarakat dengan tema Pelatihan Sistem Informasi Pencatatan Keuangan Berbasis Android ini dilaksanakan pada hari Sabtu, tanggal 14 November 2020. Kelompok sasaran pada kegiatan pengabdian kepada masyarakat ini adalah anggota Koperasi Jasa Komunitas Entrepreneur Bekasi, yaitu para pemilik usaha UMKM.

Teknik pengumpulan data dilakukan melalui kuesioner. Kepada setiap peserta setelah selesai pelatihan langsung diberikan kuesioner untuk penilaian terhadap pelaksanaan kegiatan pelatihan, tujuannya untuk mengetahui peserta puas atau tidak puas. Penilaian menggunakan skala likert yaitu: Sangat Puas $(\mathrm{SP})=4$ :, Puas $(\mathrm{P})=3$ :, Tidak Puas $(\mathrm{TP})=2:$, Sangat Tidak Puas $(\mathrm{STP})=1$.

Analisis data menggunakan evaluasi Kirkpatrick level reaksi (Level 1). Evaluasi level ini bertujuan untuk mengukur tingkat kepuasan peserta pelatihan terhadap penyelenggaraan pelatihan, mencakup kemampuan intruktur, elemen materi, penyelenggaraan, serta fasilitas sarana.

Data yang diperoleh dari pengukuran level reaksi kemudian diolah dengan metode pembobotan dari Kirkpatrick. Perhitungan bobot untuk setiap pertanyaan kuesioner yang 
digunakan untuk mengukur sebagai berikut: a) Jumlahkan nilai jawaban dari seluruh responden untuk setiap item pernyataan kuesioner, b) Tentukan nilai tertinggi pada skala pengukuran, c) Hitung jumlah responden, dan d) Hitung bobot untuk setiap item pernyataan dengan rumus di bawah ini.

$$
\text { Bobot item } \mathrm{ke}-\mathrm{i}=\frac{\text { Total nilai jawaban dari seluruh responden untuk item ke }-\mathrm{i}}{\text { Nilai tertinggi pada skala pengukuran } \mathrm{x} \text { Jumlah responden }} \times 100 \%
$$

Tabel 1. Kriteri Penilaian

\begin{tabular}{|l|l|}
\hline \multicolumn{1}{|c|}{ Range } & \multicolumn{1}{c|}{ Interpretasi } \\
\hline$<50 \%$ & Peserta menunjukkan reaksi yang kurang baik terhadap pelatihan \\
\hline $50-60 \%$ & Peserta menunjukkan reaksi yang lebih baik terhadap pelatihan \\
\hline $61-80 \%$ & $\begin{array}{l}\text { Peserta menunjukkan reaksi yang positif karena menyadari mendapat masukan } \\
\text { yang berguna selama pelatihan }\end{array}$ \\
\hline $81-100 \%$ & Peserta menunjukkan reaksi positif yang tinggi \\
\hline
\end{tabular}

(Sumber: Rukmi et al (2014)

Penyajian data hasil perhitungan dalam bentuk jumlah dan persentase serta dibuat dalam bentuk tabel. Peralatan yang digunakan pada kegiatan pengabdian kepada masyarakat ini adalah infokus serta ponsel android. Untuk itu digunakan ponsel milik masing-masing peserta. Bahan lainnya adalah berupa note book dan bolpen untuk catatan.

Metode pelaksanaan kegiatan pengabdian kepada masyarakat tentang pelatihan aplikasi keuangan berbasis android kepada anggota koperasi entrepreneur meliputi tahapan: 1). Persiapan awal, 2) Penyuluhan, 3) Praktek demontrasi contoh kasus, dan 4) Evaluasi.

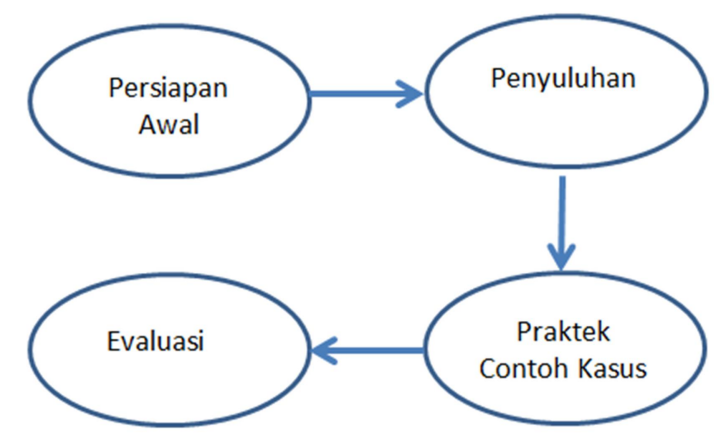

Gambar 1. Tahap Kegiatan

\section{Tahap Persiapan Awal}

Persiapan melakukan pertemuan dengan ketua koperasi, membicarakan rencana pelaksanaan kegiatan, membahas perkembangan anggota koperasi, permasalahan yang dihadapi anggota koperasi, keputusan kerjasama yang dilengkapi surat kerjasama, 
Penguatan Entrepreneur Umkm Melalui Pelatihan Sistem Informasi Pencatatan Keuangan Berbasis Android Pada Koperasi Jasa Komunitas Entrepreneur Kelurahan Perwira Bekasi Utara

Budi Indrawati, Elia Rossa, Supriyanto

memutuskan bentuk kegiatan, tempat kegiatan, perlengkapan kegiatan dan sarana, serta hari dan tanggal kegiatan.

\section{Tahap Penyuluhan}

UMKM diatur dalam UU No 20/2008 tentang UMKM. Usaha Mikro adalah suatu usaha ekonomi yang produktif milik individu atau badan usaha yang memenuhi ciri-ciri sebagai usaha mikro. Kriteria usaha mikro: apabila badan usaha tersebut memiliki kekayaan bersih mencapai/max Rp 50.000.000, tidak termasuk bangunan dan tanah. Selain itu, hasil dari penjualan usaha mikro tersebut mencapai Rp 300.000.000 dalam jangka satu tahun

Usaha Kecil menurut Undang-Undang No. 20 Tahun 2008 Tentang UMKM Usaha Kecil adalah usaha ekonomi produktif yang berdiri sendiri, dilakukan oleh perorangan atau badan usaha yang bukan merupakan anak perusahaan atau bukan cabang perusahaan yang dimiliki, dikuasai, atau menjadi bagian baik langsung maupun tidak langsung dari usaha menengah atau usaha besar. memiliki kekayaan bersih tidak termasuk tanah dan bangunan sebanyak banyaknya 200 juta atau mempunyai hasil penjualan ratarata per tahun $\mathrm{Rp} 1$ Milyar dan usaha tersebut berdiri sendiri.

Usaha Menengah adalah badan usaha milik WNI yang memiliki kekayaan bersih lebih besar dari Rp 500 Juta - Rp 10 Milyar, tidak termasuk tanah dan bangunan tempat usaha. Hasil penjualan tahunan mencapai Rp 2.500.000.000 sampai Rp 50.000.000.000.

Contoh-contoh UMKM: Industri kecil (skala rumah tangga), usaha kerajinan tangan, pedagang kecil/asongan, pertanian (sayuran, buah-buahan, tanaman hias), jasa (training, layanan internet, pengiriman barang).

Akuntansi Umum. Untuk Keseragaman Pelaporan Keuangan dan memudahkan pembuatan Laporan Keuangan, Ikatan Akuntan Indonesia membuat 5 pilar Standar Akuntansi yang Berlaku di Indonesia, yaitu :PSAK/IFRS, SAK Syariah, SAK ETAP, SAK EMKM (Entitas Mikro Kecil dan Menengah), dan Standar Akuntansi Pemerintahan.

Akuntansi UMKM. Acuannya: SAK EMKM (Standar Akuntansi Entitas Mikro Kecil dan Menengah). Tentunya acuan ini bisa digunakan jika UMKM yang bersangkutan telah memenuhi Kriteria sesuai dengan UU No 20/2008 tentang UMKM.

\section{Tahap Praktek}

Pelatihan praktek cara pencatatan keuangan dan pembuatan laporan keuangan usaha dengan sistem informasi aplikasi SIAPIK secara berurutan sebagai berikut: 
1. Download Aplikasi Si APik dari Google Play Store

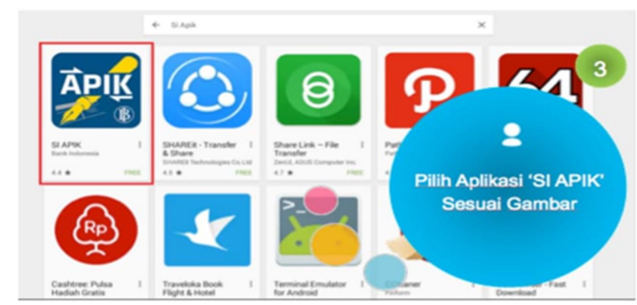

Cari : Si Apik di Google Playstore seperti gambar di Kiri Atas. Klik untuk menginstall di ponsel anda.

\section{Pilih Jenis usaha dan Isikan Saldo Awal}

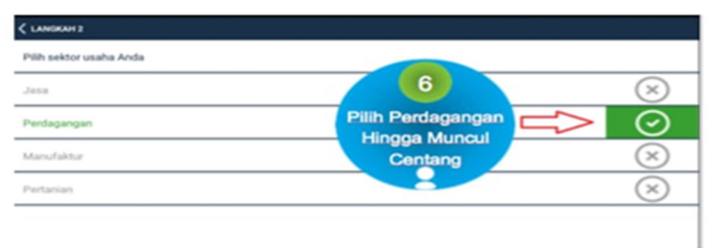

Anda bisa memilih beberapa jenis usaha yang paling cocok dengan usaha anda, apakah perdagangan, jasa atau manufaktur. Ikuti instruksi selanjutnya.

\section{2/ Mulai Menggunakan}

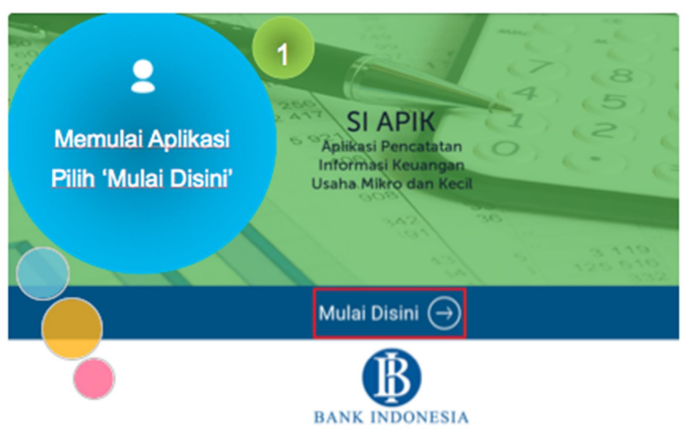

4. Catat Transaksi Pemasukan \& Pengeluaran

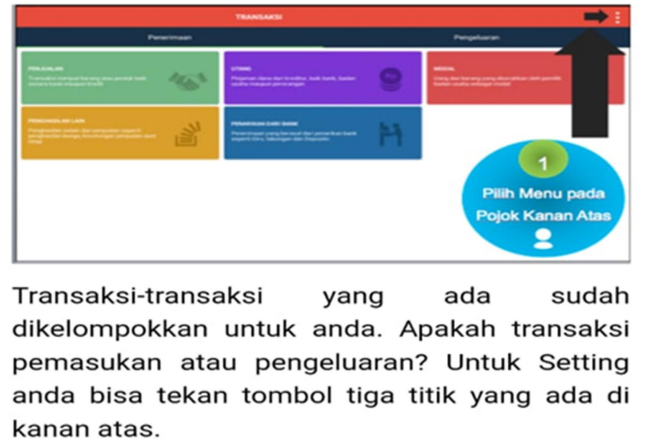

5/Buat Laporan

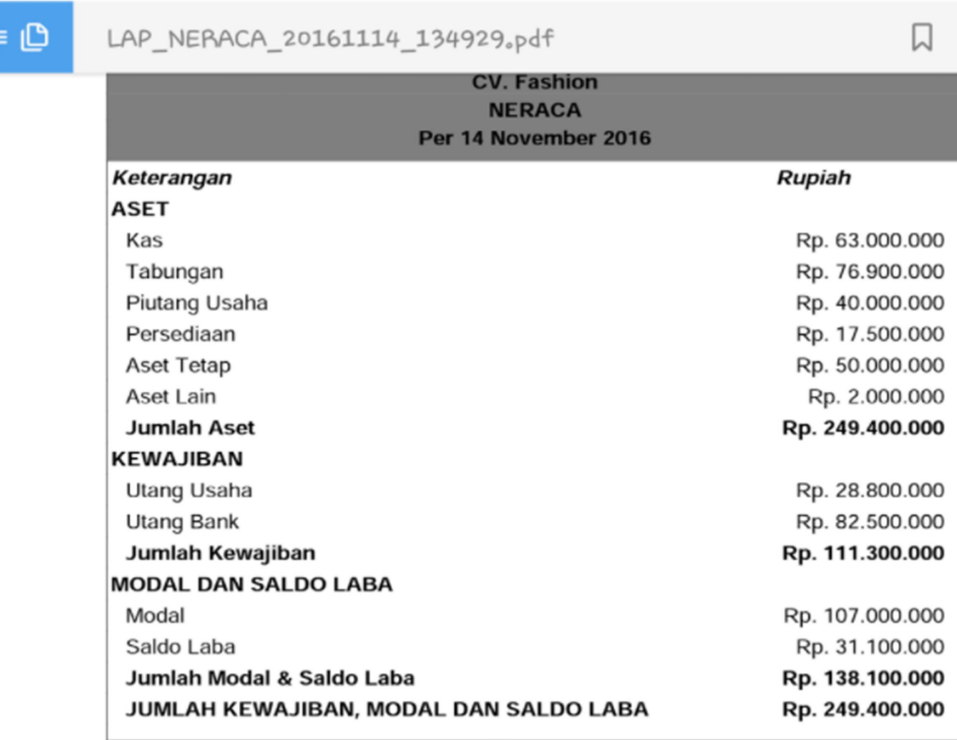

Sumber : (Daily Rudy, 2016)

\section{Tahap Evaluasi}

Pada tahap evaluasi dilakukan penelitian untuk mengetahui peserta puas atau tidak puas terhadap pelatihan keuangan berbasis android SIAPIK. 
Penguatan Entrepreneur Umkm Melalui Pelatihan Sistem Informasi Pencatatan Keuangan Berbasis Android Pada Koperasi Jasa Komunitas Entrepreneur Kelurahan Perwira Bekasi Utara Budi Indrawati, Elia Rossa, Supriyanto

\section{HASIL DAN PEMBAHASAN}

Kegiatan pengabdian kepada masyarakat dilaksanakan melalui 4 tahap, yaitu tahap persiapan awal, penyuluhan, praktek dan evaluasi. Dokumentasi kegiatan pengabdian kepada masyarakat dapat dilihat pada Gambar 1.
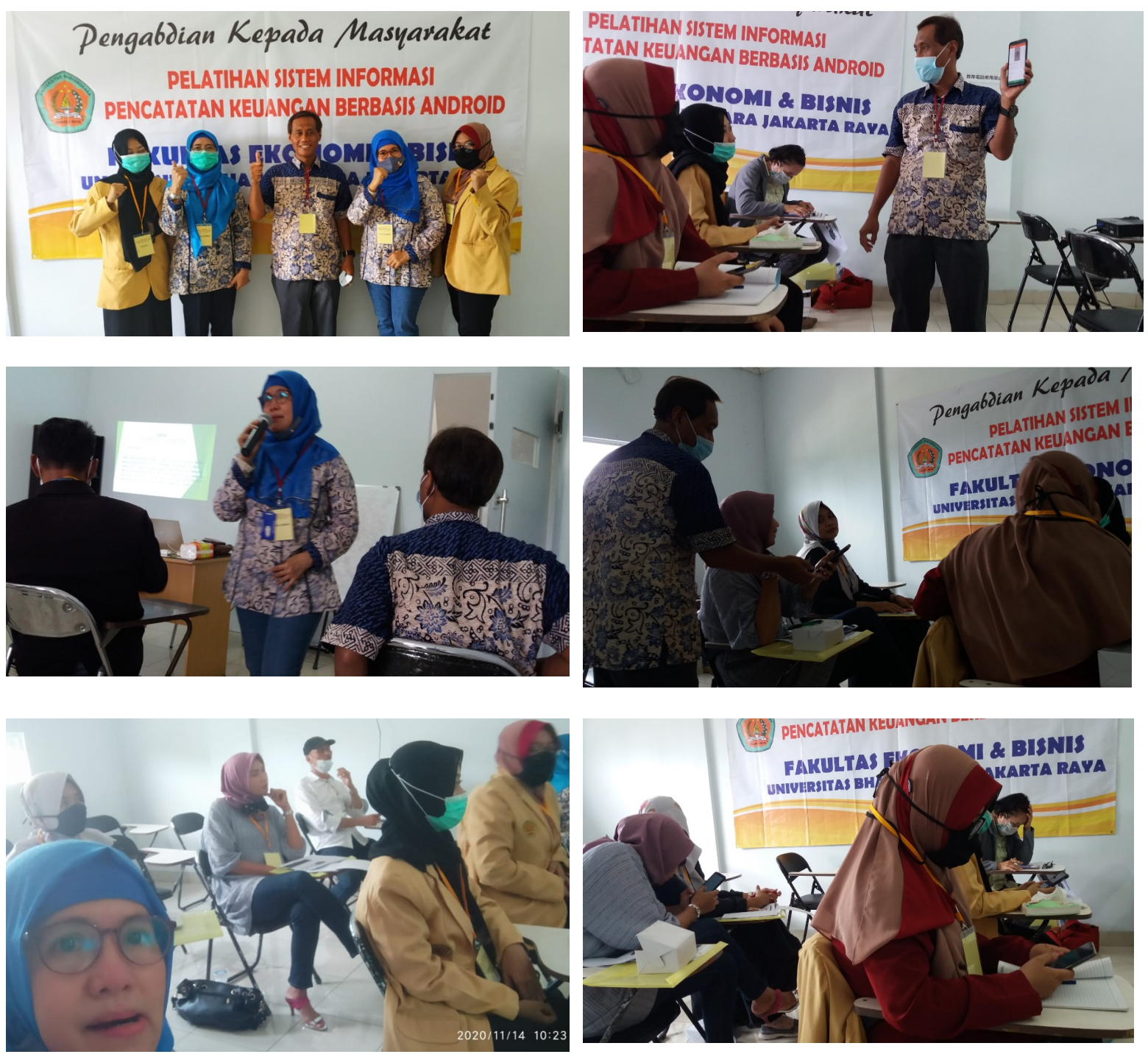

Gambar 1. Dokumentasi Kegiatan

Karakteristik responden berdasarkan gender menunjukkan bahwa pemilik usaha UMKM terbesar adalah perempuan yaitu sebesar 66,67 persen. Karakteristik responden berdasarkan usia menunjukan bahwa pemilik usaha UMKM terbesar adalah responden yang rentang usia $>50$ tahun sebesar 33,33 persen. Karakteristik responden berdasarkan pendidikan menunjukkan bahwa tingkat pendidikan responden terbesar adalah tingkat pendidikan SMA yaitu 46,67 persen. Lama usaha telah berjalan di atas satu tahun sebesar 73,33 persen. 
Hasil uji validitas terhadap pernyataan kuesioner yang terdiri atas 8 pernyataan, menunjukan pernyataan nomor 6 tidak valid karena lebih kecil dari tabel r, sehingga dikeluarkan dari daftar kuesioner, tinggal 7 pernyataan kuesioner, kemudian diuji ulang kembali dan hasilnya semua valid, karena nilainya di atas $r$ tabel. Hasil diperlihatkan pada Tabel 2.

Tabel 2. Uji Validitas

\begin{tabular}{lcccc}
\hline Variabel & Indikator & $\begin{array}{c}\text { Corrected } \\
\text { Item-Total } \\
\text { Correlation }\end{array}$ & $\begin{array}{c}\text { Nilai r } \\
\text { Tabel }\end{array}$ & Keputusan \\
\hline $\mathrm{X}$ & $\mathrm{X} 1.1$ & 0,858 & 0,707 & Valid \\
& $\mathrm{X} 1.2$ & 0,897 & 0,707 & Valid \\
& $\mathrm{X} 1.3$ & 0,980 & 0,707 & Valid \\
& $\mathrm{X} 1.4$ & 0,831 & 0,707 & Valid \\
& $\mathrm{X} 1.5$ & 0,897 & 0,707 & Valid \\
& $\mathrm{X} 1.7$ & 0,800 & 0,707 & Valid \\
& $\mathrm{X} 1.8$ & 0,731 & 0,707 & Valid \\
\hline
\end{tabular}

(Sumber : Output SPSS)

Hasil Uji Reliabilitas pada Tabel 3 menunjukkan nilai Cronbach's Alpha 0,936 berada di atas 0.7 , dengan demikian dapat disimpulkan bahwa seluruh pernyataan dalam kuesioner dinyatakan reliabel. Sehingga kuesioner yang digunakan layak untuk mengukur.

\begin{tabular}{|c|c|}
\hline \multicolumn{2}{|c|}{ Reliability Statistics } \\
\hline $\begin{array}{c}\text { Cronbach's } \\
\text { Alpha }\end{array}$ & $\mathrm{N}$ of Items \\
\hline .936 & 7 \\
\hline
\end{tabular}

Tabel 4 menjelaskan hasil penilaian peserta terhadap narasumber, materi, metode pelatihan dan fasilitas pendukung pelatihan. Diperoleh nilai bobot berada di antara 76,67 \% dan $80 \%$. Persentase terbesar terdapat pada pernyataan nomor 2 (narasumber menjawab setiap pertanyaan peserta dengan baik), nomor 4 (narasumber memberikan petunjuk memulai install aplikasi SIAPIK dengan jelas) dan nomor 5 (isi materi pelatihan sesuai dengan kebutuhan peserta), yaitu masing-masing sebesar $80 \%$. Secara rata-rata bobot sebesar 79,05 persen, Artinya ini berada di range ketiga dengan interpretasi bahwa peserta menunjukkan reaksi yang positif karena menyadari mendapat masukan yang berguna selama pelatihan. Dengan demikian disimpulkan bahwa peserta pelatihan puas terhadap pelatihan keuangan berbasis android SIAPIK. 
Penguatan Entrepreneur Umkm Melalui Pelatihan Sistem Informasi Pencatatan Keuangan Berbasis Android Pada Koperasi Jasa Komunitas Entrepreneur Kelurahan Perwira Bekasi Utara

Budi Indrawati, Elia Rossa, Supriyanto

Tabel 4. Skor dan Nilai Bobot

\begin{tabular}{|c|c|c|c|}
\hline No & Pernyataan & Skor & $\begin{array}{c}\text { Bobot } \\
\%\end{array}$ \\
\hline 1 & $\begin{array}{l}\text { Narasumber menjelaskan serta menyajikan materi secara } \\
\text { jelas }\end{array}$ & 46 & 76.67 \\
\hline 2 & $\begin{array}{l}\text { Narasumber menjawab setiap pertanyaan peserta dengan } \\
\text { baik }\end{array}$ & 48 & 80.00 \\
\hline 3 & $\begin{array}{l}\text { Narasumber memberi latihan dengan contoh pratek yang } \\
\text { mudah dipahami }\end{array}$ & 47 & 78.33 \\
\hline 4 & $\begin{array}{l}\text { Narasumber memberikan petunjuk memulai install aplikasi } \\
\text { SIAPIK dengan jelas }\end{array}$ & 48 & 80.00 \\
\hline 5 & Isi materi pelatihan sesuai dengan kebutuhan peserta & 48 & 80.00 \\
\hline 6 & $\begin{array}{l}\text { Metode pelatihan yang digunakan sudah tepat yaitu dimulai } \\
\text { penyuluhan dan dilanjutkan dengan latihan praktek. }\end{array}$ & 47 & 78.33 \\
\hline \multirow[t]{2}{*}{7} & $\begin{array}{l}\text { Sarana mendukung kegiatan pembelajaran infokus, laptop, } \\
\text { white board dan ruang AC }\end{array}$ & 48 & 80.00 \\
\hline & Jumlah dan Rata-rata & 332 & 79.05 \\
\hline
\end{tabular}

(Sumber : Data primer diolah rumus)

\section{KESIMPULAN DAN SARAN}

\section{Kesimpulan}

Justifikasi pengusul bersama mitra dalam menentukan persoalan prioritas yang disepakati untuk diselesaikan selama pelaksanaan kegiatan pengabdian kepada masyarakat (PKM) adalah masalah pencatatan keuangan dan pembuatan laporan keuangan yang efektif dan efisien. Untuk itu, solusinya diberikan pelatihan dan praktek penggunaan pencatatan keuangan dan pembuatan laporan menggunakan sistem informasi pencatatan keuangan aplikasi berbasis android SI APIK dari Bank Indonesia. Sistem ini bukan sekedar mencatat, tetapi mengandung arti luas, mulai dari mencatat keuangan, proses akuntansi hingga penyusunan laporan keuangan. Jauh lebih luas lagi bisa menyajikan hasil analisis laporan keuangan serta melihat kinerja keuangan secara lebih komprehensif.

Luaran yang diharapkan dari pelaksanaan pelatihan dan praktek tentang cara pencatatan keuangan dan membuat laporan keuangan yang efektif dan efisien dengan Aplikasi Android SI APIK, adalah anggota koperasi telah harus menggunakan sistem informasi aplikasi android pencatatan transaksi keuangan SI APIK. Dari pelatihan keuangan dengan sistem SI APIK ini maka entrepreneur UMKM: 1) Paham dan mampu membuat pencatatan keuangan dengan menggunakan SI APIK, dan 2) Paham dan mampu membuat laporan keuangan dengan menggunakan SI APIK.

Anggota koperasi entrepreneur UMKM paham dan mampu membuat sendiri pencatatan keuangan, dan paham serta mampu membuat laporan keuangan dengan menggunakan aplikasi SI APIK. Hasil evaluasi level reaksi menunjukan bahwa peserta puas dengan pelatihan penggunaan aplikasi SI APIK ini. 


\section{Saran}

Banyak permasalahan yang dihadapi anggota koperasi jasa entrepreneur (UMKM), namun dalam pelatihan yang diberikan pada kegiatan pengabdian kepada masyarakat di sini, berkaitan dengan pencatatan dan pembuatan laporan keuangan. Oleh karena itu, dapat disarankan untuk memberikan pelatihan di bidang lainnya, seperti pemasaran, kualitas produk dan jasa serta kualitas layanan.

\section{UCAPAN TERIMAKASIH.}

Kegiatan Pengabdian Kepada Masyarakat ini dapat terselenggara dengan adanya dukungan dari beberapa pihak. Untuk itu, kami mengucapkan terima kasih dan penghargaan sebesar-besarnya kepada: Dekan Fakultas Ekonomi dan Bisnis Universitas Bhayangkara Jakarta Raya. Ketua LPPMP Universitas Bhayangkara Jakarta Raya. Ketua Koperasi Jasa Entrepreneur Bekasi serta Pemilik tempat kegiatan acara.

\section{DAFTAR PUSTAKA}

Daily Rudy. (2016). si apik aplikasi akuntansi usaha mikro kecil umk berbasis android. Wordpress.Com. https://dailyrudy.wordpress.com/2016/12/26/si-apik-aplikasiakuntansi-usaha-mikro-kecil-umk-berbasis-android/

Dewi et. al. (2020). Pendampingan Penyusunan Laporan Keuangan Sederhana Menggunakan Aplikasi SIAPIK Bagi UMKM Keset Perca Di Desa Ngasinan Etan Kelurahan Gebang. JURNAL ABDIDAS, Volume $1 \mathrm{~N}$.

Entah Ismanto. (2017). Dinas Koperasi dan UMKM Fasilitasi Bantuan Permodalan Bagi Pelaku Usaha di Kabupaten Bekasi. Beritacikarang.Com. https://beritacikarang.com/dinas-koperasi-dan-umkm-fasilitasi-bantuan-permodalanbagi-pelaku-usaha-di-kabupaten-bekasi/

Indonesia, B. (2018). BI Kembangkan Aplikasi SI APIK Bantu Pencatatan Laporan Keuangan UMKM. Lensakalteng.Com. https://lensakalteng.com/2018/11/bikembangkan-aplikasi-si-apik-bantu-pencatatan-laporan-keuangan-umkm/

Ramadhan, A. M. (2016). Koperasi Untuk Entrepreneur. Wirausahabarujabar.Net. http://www.wirausahabarujabar.net/artikel-bisnis-manajemen/koperasi-untukentrepreneur/

Rinandiyana et. al. (2020). UTILIZATION OF ANDROID BASED ACCOUNTING APPLICATION (SIAPIK) TO IMPROVE FINANCIAL ADMINISTRATION OF MSMES. Jurnal Qardhul Hasan; Media Pengabdian Kepada Masyarakat, Volume 6 $N$.

Rukmi et. al. (2014). Evaluasi Training Dengan Menggunakan Model Kirkpatrick (Studi Kasus Training Foreman Development Program Di PT. Krakatau Industrial Estate Cilegon). Perpustakaan Itenas. lib.itenas.ac.id

Supriono. (2015). Pelaku UKM Di Tuntut Paham Akuntansi. Kebumenkab.Go.Id. https://www.kebumenkab.go.id/index.php/public/article/detail/92

Tambunan, T. (2012). Usaha Mikro, Kecil dan Menengah di Indonesia, Isu-Isu Penting. LP3ES Jakarta.

Wahyu, G. (2017). 5 Permasalahan Utama yang Dihadapi Para Pelaku UMKM. 
Kumparan.Com. https://kumparan.com/pahlawan-digital/5-permasalahan-utamayang-dihadapi-para-pelaku-umkm

Wiratama et. al. (2019). Penerapan Aplikasi Keuangan Berbasis Android "Si Apik" pada Penyusunan Laporan Keuangan UMKM Biofarmakaka Desa Limbangan Kendal. Rekayasa Jurnal Penerapan Teknologi Dan Pembelajaran.

Yasin, A. (2018). Pemkab Bekasi Dorong Pelaku UMKM Terapkan Bisnis e-Commerce. Beritacikarang.Com. https://beritacikarang.com/pemkab-bekasi-dorong-pelakuumkm-terapkan-bisnis-e-commerce/ 